\title{
Stakeholder Views on the Drivers and Inhibitors of Performance of Outsourced Information Technology Employees
}

\author{
Glad Dibetso, Margie Sutherland and Caren Scheepers \\ Gordon Institute of Business science \\ University of Pretoria
}

\begin{abstract}
Purpose: The purpose of this study is to empirically quantify the factors that are perceived to drive or inhibit performance of information technology (IT) outsourced employees from a range of information technology outsourcing (ITO) stakeholders in South Africa.

Design /methodology/approach: The first phase was a qualitative study on 19 stakeholders focussed on the development of the constructs. The second phase was quantitative, with a sample of 116 ITO stakeholders of the largest IT company in South Africa.
\end{abstract}

Findings: The study revealed that the ITO stakeholders had misaligned perceptions on inhibitors and somewhat congruent perceptions with regards to drivers of performance. Managers and poor performers' perceptions of inhibiting factors of performance were significantly different. The empirical evidence showed that the key drivers of performance were intrinsic factors and leadership, whilst the inhibiting factors were mainly related to poor leadership.

Research limitations/ implications: The major limitation was that the population was represented by one large organisation in the South African IT industry and its clients, thereby excluding the rest of the IT industry participants, specifically the medium and small IT companies. The quota sample resulted in a non-probability study, and thus, the results of this study may not necessarily be generalised to other populations. This study's 
findings on differences between good and poor performers must be investigated in other industries.

Practical implications: For outsourced employees to perform optimally, some key intrinsic factors must be fulfilled. Passion and pride, aligned to a meaningful job role, will unleash outstanding performance. Organisations need to ensure that there is regular feedback to managers on their performance and subsequent leadership development. Alignment of managers and poor performers' perceptions on drivers and inhibitors could improve performance.

Social implications: These findings demonstrate the large gap in perceptions about the key drivers and inhibiters of performance.

Originality/ Value: The study reveals that top performers tend to have higher order and intrinsic motivators, compared to poor performers, who have a mixture of extrinsic and intrinsic needs, and managers have a misaligned expectation of extrinsic motivators.

Keywords: Outsourcing; IT Outsourcing, Employee performance, Motivation, Stakeholders

\section{Introduction}

The introduction of outsourcing is no less significant than fundamental changes such as the industrial revolution, scientific management or the bureaucratic form (Davis-Blake and Broschak, 2009). Outsourcing is the transfer to an external provider of services that were previously carried or produced internally (Abu-Musa, 2011; Elmuti, Grunewald and Abebe, 2010; Windrum, Reinstaller and Bull, 2009) to gain economies of scale, reduce costs (Blair, O'Connor and Kirchhoefer, 2011) and to optimise scarce in-house resources (Iqbal and Munir Dad, 2013). This phenomenon has been driven by reducing operational costs and specialising in key areas (Al-Gharbi, Al-Kindi and Al-Salti, 2009; Gorla and Lau, 2010; Lacity, Khan, Yan and Willcocks, 2010; Mcivor, 2011). Information Technology (IT) 
is one of the most outsourced organisational functions (De Cavalho, Poleto and Seixas, 2017). Information Technology Outsourcing (ITO) has grown at a rapid pace. Statista (2016) reports the total contract value of the ITO market worldwide in 2015 as 88.9 billion US dollars. Global sourcing is growing two times faster than global IT spend (NASSCOM, 2015). Even though outsourcing does not always involve offshore outsourcing, using IT vendors in other countries would lead to even more complexity in the ITO relationships, especially in cross-cultural interfaces (Clarke, Chandra and Machado, 2016). Unfortunately, approximately "seventy-eight percent of the client vendor partnership fail in the long term" (Mehta and Mehta, 2010, p. 162). A key determinant of the success of outsourcing is the performance of ITO employees. However not enough is understood regarding how to optimise the performance of these outsourced employees, whose skills are scarce and costly. These knowledge workers have widely available employment opportunities coupled with competitive pay structures and do not need to remain with their present organisation because of the absence of choice (Jayasingam, Govindasamy and Garib Singh, 2016).

Stakeholders are defined as "entities or persons who are or will be influenced by, or exert an influence directly or indirectly, on the project" (Littau, Jujagiri and Adlbrecht, 2010, p. 29). In order to be sustainable organisations should aim at satisfying or exceeding the expectations of their stakeholders without compromising other parties (Garvare and Johansson, 2010). Therefore, to ensure successful stakeholder management an organisation should have a clear view of its stakeholders' various viewpoints (Abboubi and Cornet, 2012). This study therefore gathered views from several stakeholders. There are three main stakeholder groups involved in ITO, namely the client managers, who are outsourcing the IT function, the managers of the service providers, and the ITO employees, employed by the service provider but working on behalf of the client organisation. The employees are exposed to a duality of command from the two types of managers. These stakeholder groups may have different perceptions about the factors that drive or inhibit performance of the employees, but both the client and the service provider management are interested in driving performance of ITO employees (Choudhuri, Maguire and Ojiako, 2009). 


\section{Literature Review}

Given the aim of the research to investigate the drivers and inhibitors of performance of ITO employees, the literature review commences with the unique context of ITO employees, followed by an investigation into existing literature on general drivers and inhibitors of performance and intrinsic and extrinsic motivation. The literature review concludes with highlighting the need for conducting research on various stakeholders' views.

\subsection{Information Technology Outsourcing as a Unique Performance Context}

One of the most important yet daunting tasks of leaders in an organisation is to ensure employee performance through motivation and creating a productive work environment (Staren, 2009). A key determinant of the success of outsourcing is the performance of ITO employees. However, due to the unique context of the ITO environment, focused attention is required on the dynamics in this landscape. ITO creates a strategic transference of IT services to a vendor company that specialises in performing those activities (Abu-Musa, 2011). These outside resources then perform activities that are usually handled by internal staff (Elmuti et al., 2010). Both the client and the ITO management are interested in driving performance of ITO employees (Choudhuri, Maguire and Ojiako, 2009). De Cavalho et al. (2017) emphasise, "the integration between the outsourcing actors is a core aspect in the coordination of all activities necessary to organize the outsourced services for success" (p.2). Thus, the current study endeavours to conduct research into these environments, where not enough is understood, regarding how to manage the performance of these ITO employees. Interestingly, studies on outsourcing emphasise aspects around the service level agreements as crucial in the success in these outsourcing relationships (Goo, Kishore, Rao and Nam, 2009; Wagner, 2006), whereas the motivation of employees under these unique employment conditions has received limited scholarly attention.

Brooks, Miller and Korzaan (2009, p. 9) indicate that outsourcing is "negatively related to career satisfaction and general satisfaction with the profession, and positively related to 
intention to turnover from the profession". The outsourcing environment causes stress and anxiety to the employees, due to the changes in the nature of work, control and organisational design, resulting in loss of productivity (Elmuti et al., 2010). Other studies indicate that ITO increases role conflict, role ambiguity and overall stress levels (SolliSæther, 2011). Due to these significant challenges, special attention has to be given to motivational drivers and inhibitors of performance.

\subsection{Drivers of Performance}

There is a plethora of literature and much debate on the factors deemed to drive performance. Job satisfaction is a commonly cited factor. For maintaining a baseline level of job satisfaction, fair remuneration, sufficient benefits, job security related to performance, safe job environments and fair policies and procedures are required (Staren, 2009). Over and above these baseline factors, managers should consider utilising incentive-based compensation; demonstrate appropriate interpersonal behaviour and leading by positive example in order to optimise satisfaction (Staren, 2009). Proactive employees are more likely to experience job satisfaction because they tend to remove all obstacles that prevent job satisfaction (Thomas, Whitman and Viswesvaran, 2010). Other antecedents of job satisfaction include a high involvement of employees in goal setting, frequent opportunities to discuss performance, regular and timely feedback, and having some choice over remuneration and incentives (Farndale, Hope-Hailey and Kelliher, 2011). Research by Perry, Hunter and Currall (2016) indicates that knowledge workers are more committed when they understand their strategic role within the organisation and where organisations are productive.

Another group of key drivers of performance is "receiving recognition from peers, supervisors, or subordinates for one's good work performances" (Bristow, Amyx, Castleberr and Cochran, 2011, p. 78). A clear focus on non-monetary rewards such as employee recognition programmes have proven to be very effective and are usually low cost (Kaufman, 2009). Incentives have proven to be very effective in increasing performance for tasks not done before; these could be tasks that support both quality and quantity (Danish and Usman, 2010). Promotion is another form of reward important to 
employees as it creates an opportunity for personal growth and generally leads to increased responsibilities and social standing (Danish and Usman, 2010). Advancement to managerial positions has been found to increase satisfaction and commitment (Sharabi and Harpaz, 2010). Competitive individuals are more interested in obtaining personal benefits than organisational or team benefits whilst cooperative individuals tend to focus on collaboration for the benefit of the organisation (Hsu, Chen, Yu and Lou, 2010). An increase in responsibility and autonomy has been reported by most researchers to increase job satisfaction (Sharabi and Harpaz, 2010).

The role of remuneration in driving performance is much debated. Remuneration is one of the most important outcomes of work, with some authors viewing it as the biggest contributor to overall job satisfaction. "Pay satisfaction is also important because it has serious implications on individual performance, absenteeism, labour turnover" (Bhanu, 2011 , p. 113). On the other hand, some researchers argue that money is a poor motivator and can actually impede intrinsic motivation such as innovation and creativity and thus reduce employee performance (Stringer, Didham and Theivananthampillai, 2011). For simple, straight forward tasks, Saklani (2010) found greater monetary reward will lead to more tasks being completed. However, when tasks get more complicated and require some conceptual creative thinking, then remuneration does not drive performance. Herzberg's seminal hygiene theory says organisations need to pay people "enough" but then three factors lead to better performance, once money as a hygiene factor has been satisfied: autonomy, mastery and purpose (Carleton and Canada, 2011; Harell and Daim, 2010). To increase job satisfaction, organisations must focus on motivating factors and adapt job roles accordingly (Baldonado and Spangenburg, 2009; Guha, 2010).

Employees derive high levels of job satisfaction when they achieve success in mentally challenging occupations where their skills and abilities are fully utilised. Encouraging employees to participate in organisational decisions may make employees feel valued (Danish and Usman, 2010). Research has shown that a greater sense of wellbeing is achieved when people find meaning in life and that one's career is a central component of a sense of calling (Hirschi, 2011) indicating that people are not just about profit 
maximisation but also about purpose maximisation. IT professionals need to constantly be up to date with knowledge and skills sets "unlike other professionals where basic knowledge remains enduring, the half-life of knowledge and skills in the IT profession is estimated at less than two years" (Fu, 2010, p. 274). The threat of erosion of competencies may cause a further threat of professional obsolescence which will inhibit performance (Fu, 2010). Employee development aims to develop an individual's abilities and results in increased performance and organisational success (Hameed and Waheed, 2011). Ongoing informal coaching allows managers to treat employees as personal partners in achieving both personal and organisational goals (Hameed and Waheed, 2011).

Workplace enjoyment is often cited as important to performance. Some authors advocate integrating work and play (Lamm and Meeks, 2009). Others discuss how work environments which do not allow for creativity and innovation, but are full of gossip, distrust and fear, or have stifling systems and structures with a deep vertical hierarchy, where employees have little to no power, will have lower performance levels (Pryor, Singleton, Taneja and Humphreys, 2010).

Fu (2010) found that IT professionals have lower social needs and a higher need for achievement than non-IT individuals. However, researchers have found that interpersonal respect amongst members of a group results in benefits such as extra effort being expended (van Quaquebeke, Zenker and Eckloff, 2008). In his study Saklani (2010) found that environmental factors such as physical environment, safety and other related working conditions are important to the employees in regards to quality of work life. The temporal nature of the outsourcing contracts can have a negative impact on employee morale (Brooks, Miller, \& Korzaan, 2009), cause role ambiguity, stress (Solli-Sæther, 2011) and anxiety due to the changes in the nature of work, control and organisational design and loss of job security (Elmuti et al., 2010).

The role of management is another common theme in the literature. Sharkie (2009) argues that it is through trust that subordinates are motivated to achieve above average performance. Trust also leads to high levels of organisational commitment and 
performance, for example negative feedback from a trusted manager will be considered as accurate and the subordinate will attempt to improve their performance whilst the same feedback from an untrusted manager will be doubted (Farndale et al., 2011). Employees also need appropriate resources to perform jobs in an effective and efficient manner (Schraeder and Jordan, 2011).

The wide range of factors affecting employees' performance is well summarised by Saklani (2010, p.90) who says the essence of quality of work life is, "the existence of a 'work environment' which is a matter of certain humanistic and life enhancing work experience characteristics... working conditions and management practices, such as, reasonable pay, healthy physical environment, employees welfare, job security, equal treatment in job related matters, grievance handling, opportunity to grow and develop, good human relations, participation in decision making and balance in life."

The above discussion revolved around drivers of performance in general, however given the unique conditions under which employees in the ITO environment conduct their daily work the researchers investigated the first research question: What are the factors that are perceived as driving ITO employees' performance?

\subsection{Inhibitors of Performance}

Attributions by managers about the causes of the poor performance predict their responses to poor performers (Ferguson, Ormiston and Moon, 2010, p. 305). Individual employees perform at different levels and each employee performs at varying levels over a time period, going through peaks and troughs (Lee and Dalal, 2011). Managers who decide that the poor performance is within the poor performer's control may respond differently than those who conclude that the cause of the poor performance is due to uncontrollable circumstances (Ferguson et al., 2010). Mayfield and Mayfield (2011) argue that low and high performers know how they are performing but medium performers need the most feedback. They say high performers may need some guidance, praise and no micro-management, whilst poor performers will require frequent counselling, clear performance targets and well-articulated ramifications. 
Job security is likened to Maslow's second most important need of safety (Sadri and Bowen, 2011). Studies revealed that ITO employees are very concerned about issues of security due to the contractual nature of outsourcing and about training, development and promotion opportunities (Walsh and Deery, 2006). Employees derive a sense of safety knowing that they are able to provide for themselves currently and in the long term (Sadri and Bowen, 2011). As discussed previously IT professionals need to constantly be up to date with knowledge and skills sets (Fu, 2010, p. 274). The threat of erosion of competencies may cause a further threat of professional obsolescence which will inhibit performance (Fu, 2010).

Starratt and Grandy (2010) emphasise that abusive leadership causes feelings of hopelessness, humiliation and anxiousness at a personal level and result in employee turnover and a destructive organisational culture. Kernan, Watson, Chen and Kim (2011) argued that the effects of abusive leadership include amongst others, diminishing psychological wellbeing and quality of work life with the effects spilling over to employees' personal lives. The perception of excessive bureaucracy and red tape can frustrate employees and lead to demotivation, for example when centralised decision making processes take too long they add to employee frustration and lead to reduction of selfefficacy and motivation (Paarlberg and Lavigna, 2010). Employees need appropriate resources to perform jobs in an effective and efficient manner (Schraeder and Jordan, 2011). The second research question was formulated as: What are the factors that are perceived as inhibiting ITO employees' performance?

\subsection{Intrinsic and Extrinsic Motivation}

Deci and Ryan (2000) defined motivation as a continuum between intrinsic on the one side, where an employee is motivated by the work itself, and on the other side, extrinsic motivation, due to the outcome, for example, status, achievement or recognition. Their contribution is a reinforcement theory of motivation, where the influence of the work environment could create conditions of enabling or diminishing of motivation. Intrinsically motivated people often have occupation commitment (Yousaf, Yang and Sanders, 2015) 
which can be enhanced by creating opportunities for employees to connect with their professional network.

The seminal theory of motivation, Maslow's hierarchy of needs, show that needs range from the lowest or most basic physiological needs, to the highest or self-actualisation needs (Sadri and Bowen, 2011). Intrinsic and extrinsic motivation can be related to Maslow's hierarchy of needs. At the lower levels of the Maslow's pyramid, the employees are interested in remuneration, job security and a sense of belonging and are motivated by extrinsic factors. At the top of the Maslow's pyramid, employees seem to be driven by a sense of purpose, autonomy and recognition i.e. intrinsic factors rather than what managers offer. These factors can be strong enough to ensure that the employee overcomes most obstacles even in an environment that does not have ideal human resource processes. This juxtaposition of the two approaches towards motivation has compelling implications for managers who need to understand where their employees are located, in order to apply appropriate management practices. Employees at the base of the pyramid need to be provided with extrinsic factors such as job security, pay and reassurance to result in improved performance; whilst employees at the top of the pyramid need to provide with intrinsic motivating opportunities such as via independence to ensure high performance and commitment.

The literature reveals a plethora of views regarding the factors impacting on the performance of employees. No research could be found that focuses on analysing the drivers and inhibitors of performance of outsourced IT employees.

\subsection{Stakeholder's Perceptions in ITO}

Stakeholders are defined in this paper as ". . entities or persons who are, or will be influenced by, or exert an influence directly or indirectly on the project" (Littau, Jujagiri and Adlbrecht, 2010, p. 29). At the centre of stakeholder theory is the notion that an organisation should aim at satisfying or exceeding the expectations of its stakeholders without compromising other parties (Garvare and Johansson, 2010). Assudani and Kloppenborg (2010) emphasise the importance of aligning expectations of stakeholders. 
As a result, this study's aim is to understand the expectations of the identified stakeholders in order to drive performance of ITO employees. Louw, Sutherland and Hofmeyr (2012) found that there is a non-alignment between what managers and employees believe drives and inhibits performance. Scholarly research in other fields has emphasised that humans can even be involved in the same physical activity, but embrace it very differently, leading to the requirement for studies into the dynamics and complexity involved in a people-based process consisting of interfaces (Padin, Svensson and Wood, 2016). As a result, it is worth investigating the multiple perspectives of stakeholders involved in ITO. The particular stakeholders' views under investigation in this study are:

- IT client managers, who are IT managers from the companies that are outsourcing IT functions to service providers.

- ITO service provider managers, defined as managers of ITO employees who are part of the vendor/service provider company rendering services to the client company.

- ITO employees are the employees working for the vendor/service provider company that is providing IT services to the client company. These employees are divided into those viewed as being either "good" or "poor" performers.

These stakeholder groups may have different perceptions regarding the factors that drive or inhibit performance. This study unpacks these differences to assist ITO service managers and client managers to align their perceptions, seeing that they both have vested interest in improving performance of ITO employees (Choudhuri, Maguire Ojiako, 2009). This joint partnership strategy is due to the realisation that "vendor's human resource - related issues are a key source of risk for client's IT projects. To mitigate this risk, clients aspiring to be outsourcing-centric can help their vendors develop robust human resource management policies and practices" (Mehta and Mehta, 2010, p. 162). Given the importance of understanding the varying views of the key stakeholder groups the third research question was: Do the perceptions of the factors that influence ITO employees' performance differ between ITO client managers, ITO service provider managers and highly and poorly performing ITO employees? 


\section{Methods}

\subsection{Research Methodology}

The research was conducted in two phases. The first phase of the research was qualitative to develop and validate the constructs used for phase two. The second phase was a quantitative survey. The study thus utilized the mixed method research methodology that enabled the researchers to combine both qualitative or inductive (discovery of patterns) and quantitative or deductive (testing of hypotheses) approaches (Johnson and Onwuegbuzie, 2004). Yin (2011) contends that mixed methods take advantage of the similarities and differences in qualitative and quantitative methods.

3.1.1 Phase One: Qualitative research was chosen as it "is great for addressing 'how' questions - rather than 'how many'; for understanding the world from the perspective of those studied; and for examining and articulating processes" (Pratt, 2009, p. 856). It combined the findings from the literature review above and the insights of members of the four identified stakeholder groups in order to generate valid constructs for phase two.

The study was conducted in one company to mitigate the effect of extraneous variables on the perceptions of respondents. The company selected for this study has a large number of IT outsource employees, which was the focus of the study. As the largest IT company in South Africa, the company employs over 14000 skilled employees worldwide and the ITO division employs in excess of 3000 employees worldwide.

This study was conducted with the stakeholders of this IT company. Four stakeholder subsamples were used: Client managers, who are IT managers from the companies that are outsourcing IT functions to service providers; ITO service provider managers, defined as managers of ITO employees who are part of the service provider company rendering services to the client company; ITO employees are the employees working for the service provider company but are placed at the client company. They were divided into two categories, poor and good performers. The rating of performance was defined by the organisation's human resource rating system. Good performers were defined as those employees who had been rated 'excellent' and 'very good' in the previous year's 
performance management cycle whilst poor performers were those who had been rated 'average' and 'below average'. Non-probability quota sampling techniques (Zikmund, Babin, Carr and Griffin, 2010) were used to access the respondents. Table 1 below depicts the breakdown of the sample of 19 for Phase 1.

Table 1: Samples for Phase 1 and 2

\begin{tabular}{|l|l|l|}
\hline Sample groups & \multicolumn{1}{|c|}{ Phase 1 } & Phase 2 \\
\hline IT Client managers & 2 & 31 \\
\hline IT Service providers & 7 & 30 \\
\hline $\begin{array}{l}\text { IT Outsourced employees: } \\
\text { Good performers }\end{array}$ & 7 & 27 \\
\hline $\begin{array}{l}\text { IT Outsourced employees: } \\
\text { Bad performers }\end{array}$ & 3 & 28 \\
\hline Total & 19 & 116 \\
\hline
\end{tabular}

The sample was emailed a self-administered open-ended questionnaire in line with exploratory research practices to uncover constructs from the viewpoint of the various stakeholders. This survey method made a larger sample possible, as the respondents were geographically spread. The open-ended nature of the questionnaire is consistent with the qualitative method. An email survey was chosen due to the benefits of speed of distribution and return (Zikmund et al., 2010) and all of the participants regularly deal with the organisation via e-mail. The questions asked were "What in your opinion makes outsourced IT employees work hard?" and "In your opinion what stops outsourced IT workers from working hard?". These are terms that people in IT environments regularly use and thus the researchers used them in this open-ended manner to explore perceptions on drivers and inhibitors of performance of ITO employees. Out of the 26 questionnaires that were distributed, nineteen were completed resulting in a $73 \%$ response rate. It was found that the 'poor' performers took the longest time to respond compared to all the other groups. The respondents mentioned on average 7 items for each of the questions. Content analysis was done on the open-ended data to establish 
the constructs identified to drive or inhibit ITO employees' performance (Zikmund et al., 2010). It was found that there was data saturation after 19 responses were analysed. The constructs emerging from the data analysis were combined with the factors identified in the literature review. They revealed a wide range of components thought to drive and inhibit performance. A number of the constructs from the data gathering in this phase had not been reported in the literature. All the identified constructs were used to develop the data collection instrument for Phase Two.

3.1.2 Phase Two: This phase used a quantitative survey method to extract numerical data from the stakeholders. A survey was selected as it provides a rapid, efficient and precise means of assessing information about the population (Zikmund et al., 2010). The questionnaire was self-administered over the internet as all the respondents had access to computers and internet and were familiar with technology. This phase was conducted in the same IT company and its clients as phase 1 and using the same definitions for the subsamples. Non-probability quota sampling was selected to avoid under-representation or over-representation of the subsamples (Zikmund et al., 2010). Table 1 above shows the breakdown of the sample of 116 respondents of phase 2 and that similar numbers from each subsample were attained.

The questionnaire was built by combining constructs from phase 1 and the literature review. The large number of constructs identified in phase 1 that had not been mentioned in literature shows the value of conducting phase 1. The resulting 31 drivers and 37 inhibitors of performance are shown in the left-hand columns and their sources are shown in the right hand columns of Tables 2 and 3 . The tables illustrate how the literature review and phase one were input sources into phase two. 


\section{Table 2: Questionnaire Justification for the Drivers of Performance and Total Group Means. $n=116$}

\begin{tabular}{|c|c|c|c|}
\hline Drivers of Performance & $\begin{array}{l}\text { Total Group } \\
\text { Mean }\end{array}$ & Literature review & $\begin{array}{l}\text { Phase } \\
\text { One }\end{array}$ \\
\hline Being passionate about my work & 4.39 & & $\sqrt{ }$ \\
\hline Pride in my own work & 4.32 & & $\sqrt{ }$ \\
\hline Inspiring leadership & 4.29 & & $\sqrt{ }$ \\
\hline Finding my work meaningful & 4.25 & Hirschi (2011) & \\
\hline Managers respect my contribution & 4.19 & Louw et al (2012) & \\
\hline Good relationship with clients & 4.17 & Louw et al (2012) & \\
\hline $\begin{array}{l}\text { Being provided with adequate resources } \\
\text { to do my job }\end{array}$ & 4.14 & Schraeder and Jordan (2010) & $\sqrt{ }$ \\
\hline Sense of achievement & 4.14 & $\mathrm{Fu}(2010)$ & \\
\hline A challenging job & 4.13 & Louw et al (2012) & $\sqrt{ }$ \\
\hline Good team spirit & 4.12 & & $\sqrt{ }$ \\
\hline Flexibility with regards to time and place of work & 4.10 & Louw et al (2012) & \\
\hline Financial recognition & 4.09 & Bhanu (2011) & $\sqrt{ }$ \\
\hline Reporting to an understanding manager & 4.09 & Louw et al (2012) & $\sqrt{ }$ \\
\hline Trustworthy team & 4.07 & Louw et al (2012) & $\sqrt{ }$ \\
\hline Merit based promotions & 4.07 & Louw et al (2012) & \\
\hline My job enables me to achieve my personal goals & 4.06 & Danish and Usman (2010) & \\
\hline Career growth opportunities & 4.04 & Louw et al (2012) & $\sqrt{ }$ \\
\hline Good communication from management & 4.03 & & $\sqrt{ }$ \\
\hline Accountability given with authority & 4.01 & Louw et al (2012) & \\
\hline Participative decision making & 3.96 & Saklani (2010) & $\sqrt{ }$ \\
\hline Getting regular feedback from managers & 3.96 & Louw et al (2012) & $\sqrt{ }$ \\
\hline Having fun at work & 3.92 & Pryor et al (2010) & $\sqrt{ }$ \\
\hline Job security & 3.90 & Louw et al (2012) & $\sqrt{ }$ \\
\hline Sense of belonging with my employer & 3.82 & Louw et al (2012) & \\
\hline Clear key performance indicators & 3.78 & Louw et al (2012) & \\
\hline Autonomy to make decisions & 3.78 & Sharabi and Harpaz (2010)) & $\sqrt{ }$ \\
\hline Receiving coaching and mentorship & 3.75 & Louw et al (2012) & \\
\hline Sense of belonging with client & 3.71 & & $\sqrt{ }$ \\
\hline Acknowledgement of good work & 3.68 & Louw et al (2012) & $\sqrt{ }$ \\
\hline Incentives such as all-expense paid holiday & 3.53 & Kaufman (2009) & \\
\hline Having friends at work & 3.24 & & $\sqrt{ }$ \\
\hline
\end{tabular}




\section{Table 3: Questionnaire Justification for the Inhibitors of Performance and Total Group Mean. $n=116$}

\begin{tabular}{|c|c|c|c|}
\hline Inhibitors of Performance & $\begin{array}{l}\text { Total Group } \\
\text { Mean }\end{array}$ & Literature review & $\begin{array}{l}\text { Phase } \\
\text { One }\end{array}$ \\
\hline Being disrespected by management & 4.09 & Louw et al (2012) & \\
\hline $\begin{array}{l}\text { Consistent negative criticism from } \\
\text { management }\end{array}$ & 4.06 & & $\sqrt{ }$ \\
\hline Poor decision making by managers & 4.06 & Louw et al (2012) & \\
\hline Lack of management support & 4.04 & Louw et al (2012) & $\sqrt{ }$ \\
\hline $\begin{array}{l}\text { Unfair treatment of employees by } \\
\text { management }\end{array}$ & 4.02 & Louw et al (2012) & $\sqrt{ }$ \\
\hline Lack of appropriate resources to do the job & 4.00 & Schraeder and Jordan (2011) & \\
\hline Poor communication from management & 3.97 & Louw et al (2012) & \\
\hline Personal threats to job security & 3.94 & Louw et al (2012) & $\sqrt{ }$ \\
\hline $\begin{array}{l}\text { Autocratic (oppressive) management } \\
\text { style }\end{array}$ & 3.92 & Louw et al (2012) & \\
\hline $\begin{array}{l}\text { Unclear roles and } \\
\text { responsibilities }\end{array}$ & 3.85 & Louw et al (2012) & \\
\hline Leadership indecisiveness & 3.84 & Louw et al (2012) & \\
\hline Feeling excluded & 3.84 & & $\sqrt{ }$ \\
\hline $\begin{array}{l}\text { Lack of knowledge and skills needed to do } \\
\text { my work }\end{array}$ & 3.83 & & $\sqrt{ }$ \\
\hline Bureaucracy (red tape) & 3.82 & Louw et al (2012) & $\sqrt{ }$ \\
\hline Poor working conditions & 3.82 & $\sqrt{ }$ & $\sqrt{ }$ \\
\hline Lack of trust from management & 3.80 & Louw et al (2012) & $\sqrt{ }$ \\
\hline Unrealistic targets & 3.79 & Louw et al (2012) & $\sqrt{ }$ \\
\hline Unhappiness with my pay & 3.79 & Bhanu (2011) & $\sqrt{ }$ \\
\hline Lack of career development & 3.77 & Louw et al (2012 & $\sqrt{ }$ \\
\hline Being micro managed & 3.67 & Pryor et al (2010) & \\
\hline $\begin{array}{l}\text { Lack of professionalism from team } \\
\text { members }\end{array}$ & 3.66 & & $\sqrt{ }$ \\
\hline Lack of training & 3.66 & Louw et al (2012 & $\sqrt{ }$ \\
\hline Lack of incentives & 3.64 & & $\sqrt{ }$ \\
\hline Lack of disciplined team members & 3.59 & & \\
\hline Lack of client commitment & 3.57 & & $\sqrt{ }$ \\
\hline Constant interruptions & 3.55 & & $\sqrt{ }$ \\
\hline Poor staff selection by managers & 3.54 & & $\sqrt{ }$ \\
\hline Too many changes in job requirements & 3.53 & Louw et al (2012) & \\
\hline Stress & 3.52 & & $\sqrt{ }$ \\
\hline
\end{tabular}




\begin{tabular}{|l|c|c|c|}
\hline Lack of physical wellness & 3.50 & & $\sqrt{ }$ \\
\hline Management overruling my decisions & 3.45 & Danish and Usman (2010) & $\sqrt{ }$ \\
\hline Lack of self-worth & 3.41 & & $\sqrt{ }$ \\
\hline No sense of belonging with employer & 3.41 & & $\sqrt{ }$ \\
\hline Lack of challenges in my job & 3.28 & Louw et al (2012) & $\sqrt{ }$ \\
\hline Personal problems & 3.16 & & $\sqrt{ }$ \\
\hline No sense of belonging with client & 3.14 & & $\sqrt{ }$ \\
\hline Working long hours & 3.03 & Louw et al (2012) & $\sqrt{ }$ \\
\hline
\end{tabular}

A five-point Likert-scale was used on each variable with 1 being, "does not drive/ inhibit performance" and 5 being, "drives/inhibits performance to a great extent." The questionnaire was pre-tested on four representatives from each sub-sample to determine whether the questionnaire was understandable and suited to purpose (Zikmund, 2010). Subsequently a range of adjustments were made. A URL link was sent out to the sample by email. The link directed respondents to Google Forms where they could self-administer and return the questionnaire. 116 fully completed questionnaires were returned.

The data was subjected to descriptive statistics to answer research questions 1 and 2. ttests with an alpha value set at 0.05 were used to test for differences between the stakeholder groups for research question 3 . The study was approved firstly by the company involved and subsequently by the ethics committee of the university under whose ambit this research was done.

3.3 Research Limitations: The major limitation was that the population was represented by one large organisation in the South African IT industry and its clients, thereby excluding the rest of the IT industry participants, specifically the medium and small IT companies. The study was conducted using a quota sample which made this a non-probability study. Therefore, the results of this study may not necessarily be generalised to other populations with any confidence (Zikmund et al, 2010). Another limitation of the study is that good and poor performance are evaluated based on previous years' performance of employees. There is a possibility that an otherwise high performer may have not performed well in one particular year and vice versa. 


\section{Results}

4.1 Research Question 1 - What are the factors that are perceived as driving ITO employees' performance?

Table 2 above shows the ranked ordered means of the drivers of performance for the total sample. The table is ranked from the perceived highest driver of performance to the lowest using the 'Total Group Mean' column. To further process the most important factors driving ITO performance, the top ten variables in Table 2 have been grouped in Table 4 below into themes, first by whether they are intrinsic or extrinsic motivators and then into more detailed themes. The right-hand column shows where each item is ranked in the top ten.

Table 4: Top Ten Drivers of Performance

\begin{tabular}{|c|c|c|c|}
\hline $\begin{array}{l}\text { Intrinsic/Extrinsic } \\
\text { motivator }\end{array}$ & Theme & Drivers of Performance & \begin{tabular}{|l|} 
Ranking \\
out of 31
\end{tabular} \\
\hline \multirow{5}{*}{ Intrinsic } & \multirow{5}{*}{ Purpose } & Being passionate about my work & 1 \\
\hline & & Pride in my own work & 2 \\
\hline & & Finding my work meaningful & 4 \\
\hline & & Sense of achievement & 8 \\
\hline & & A challenging job & 9 \\
\hline \multirow{5}{*}{ Extrinsic } & \multirow[t]{2}{*}{ Leadership } & Managers respect my contribution & 5 \\
\hline & & Inspiring leadership & 3 \\
\hline & \multirow{3}{*}{$\begin{array}{l}\text { Work } \\
\text { Environment }\end{array}$} & Good relationship with clients & 6 \\
\hline & & $\begin{array}{l}\text { Being provided with adequate } \\
\text { resources to do the job }\end{array}$ & 7 \\
\hline & & Good team spirit & 10 \\
\hline
\end{tabular}

It is important to note that all the top ten drivers of performance have one common theme namely, non-tangible reward. The overriding theme is about having a sense of purpose in the form of pride and passion for one's work which is meaningful and challenging and leads to a sense of achievement. The literature supports the importance of these intrinsic drivers of performance for knowledge workers. Carleton and Canada (2011) as well as 
Harell and Daim (2010) found that three factors lead to better performance once money as a hygiene factor has been removed; these are autonomy, mastery and purpose. Employees derive high levels of job satisfaction when they achieve success in mentally challenging occupations where their skills and abilities are fully utilised (Danish and Usman, 2010). The findings agree with Fu (2010) who found that IT professionals have a higher need for achievement than non-IT individuals

The next theme evident in the top ten drivers of ITO performance is extrinsic and relates to leadership which is ranked at third and fifth. Inspiring leaders and those that recognise the employees' contribution are particularly valued. Leadership as an important driver of performance in organisations is widely acknowledged (Staren, 2009). 'Managers respect my contribution' is important as employees want to do a good job and get recognised for it (Denton, 2010, p.11).

The third cluster of drivers relate to the experience of working in a team at the client organisation. Good team spirit and having a good relationship with clients were constructs developed from phase 1 of the research and were not covered in the literature review. This new insight suggests that outsourced employees value collaboration and team work. Having the needed resources is a fundamental need in the ITO environment. When substandard performance is a concern, managers are advised to investigate whether employees have sufficient resources to perform their tasks (Schraeder and Jordan, 2011). In ITO, employees are client facing and spend most of their time at the client premises. It is therefore gratifying that they deem a good relationship with the clients to be a major driver of their performance.

The five least important drivers as shown at the bottom of Table 2 provide a guide regarding what type of motivational activities not to prioritise, as they are the least effective in the ITO space. They were: having friends at work; incentives such as allexpenses paid holiday; acknowledgement of good work; sense of belonging with client, as well as receiving coaching and mentoring. These findings illustrate what $\mathrm{Fu}$ (2010) found, that IT professionals have lower social needs than non-IT individuals. The data shows that ITO employees are not interested in workplace "enjoyment", having a sense 
of belonging or acknowledgement in a one to one relationship. These are people who have chosen to move from one outsource contract to the other, due to the cyclical and transitory nature of outsourcing. It is clear from these results that ITO employees have a transactional psychological contract with both the employer and the client. This concurs with Drummond (2010) who found that IT consultants reported that their psychological contracts were unstable or flexible in nature, suggesting that they are open to changes in expectations of work roles or functions.

In summary, these ITO employees are driven by intrinsic motivators, focusing on pride, esteem and self-actualization which is enabled through great leaders and they display low social needs.

4.2 Research Question 2 - What are the factors that are perceived as inhibiting ITO employees' performance?

Table 3 above shows the results of the perceived inhibitors of performance of ITO employees. The table has been ranked ordered from the highest inhibitor of performance to the lowest using the 'Total Group Mean' column. In order to cluster the most important factors inhibiting ITO performance, the top ten variables have been grouped in Table 5 below into whether they are intrinsic or extrinsic motivators and then into more detailed themes. The right-hand column shows where each item is ranked in the top ten inhibitors. 
Table 5: Top Ten Inhibitors of Performance

\begin{tabular}{|c|c|c|c|}
\hline $\begin{array}{l}\text { Intrinsic/Extrinsic } \\
\text { ally motivated }\end{array}$ & Theme & Inhibitors of Performance & $\begin{array}{l}\text { Ranking } \\
\text { out of } 37\end{array}$ \\
\hline \multirow{10}{*}{ Extrinsic } & \multirow{7}{*}{ Poor Leadership } & $\begin{array}{l}\text { Being disrespected by } \\
\text { management }\end{array}$ & 1 \\
\hline & & $\begin{array}{l}\text { Consistent negative criticism from } \\
\text { management }\end{array}$ & 2 \\
\hline & & Poor decision making by managers & 3 \\
\hline & & Lack of management support & 4 \\
\hline & & $\begin{array}{l}\text { Unfair treatment of employees by } \\
\text { management }\end{array}$ & 5 \\
\hline & & $\begin{array}{l}\text { Poor communication from } \\
\text { management }\end{array}$ & 7 \\
\hline & & $\begin{array}{l}\text { Autocratic (Oppressive) } \\
\text { management style }\end{array}$ & 9 \\
\hline & $\begin{array}{l}\text { Outsourcing } \\
\text { Industry Related }\end{array}$ & Personal threats to job security & 8 \\
\hline & \multirow{2}{*}{\begin{tabular}{|l} 
Basic Human \\
Resource \\
Processes
\end{tabular}} & $\begin{array}{l}\text { Lack of appropriate resources to do } \\
\text { the job }\end{array}$ & 6 \\
\hline & & Unclear roles and responsibilities & 10 \\
\hline
\end{tabular}

The main finding of this study is that poor leadership is the most important contributor to hampering performance of the ITO employee. The findings illustrate that ITO employees are discouraged by leaders who disrespect them, give consistent negative feedback, are oppressive and have bad communication skills. This study has shown the multiple aspects of poor leadership which are key to inhibiting performance. Whilst a range of literature discusses the importance of leadership, it does not often show the extent of the negative impact it can have. Higgs (2009) argued that abuse of power and over-exercise of control by leaders has a negative impact on staff morale and productivity. Abusive leadership can cause feelings of hopelessness and humiliation resulting in poor employee performance (Starratt and Grandy, 2010). Kernan et al. (2011) confirm that the extent of the impact of abusive leadership depends on the cultural values of the employees. It is very clear that ITO employees have low tolerance to poor leadership. 
It is also not surprising to see that the ITO stakeholders rate 'Job Security' as a key inhibitor of performance. This is important particularly for employees in the outsourcing industry due to the typical cycle of three to five year contracts. It was noted that the respondents rated 'Job Security' very low as a driver of performance and on the other hand rated it very high as an inhibitor of performance. Similarly, unclear roles and responsibilities appeared in the top ten inhibitors, whilst clear key performance indicators appeared on the bottom ten drivers of performance. Clear roles and responsibilities will not drive performance; however, the lack thereof will inhibit performance. These findings relate to the seminal theory of hygiene and motivator factors of Herzberg operating in very different ways (Guha, 2010). The lack of appropriate resources is highly impactful on ITO employees, coming in as the sixth most important inhibitor. This makes sense given the fast-paced IT industry where employees are constantly keeping up with technological advancements. "These resources run the gamut, from office supplies, cutting edge computer equipment, latest release software, and financial resources to additional staffing" (Schraeder and Jordan, 2011, p. 6).

The five least important inhibitors of ITO performance as shown in Table 3 include working long hours; no sense of belonging with client; personal problems; lack of challenges in my job and no sense of belonging with employer. This study thus revealed that for ITO employees the lack of a feeling of belonging does not inhibit performance. This could be related to the choice of ITO as a career and the transactional relationship they have with their employers and client. The data shows that the lack of sense of belonging does not inhibit their performance and does not drive their performance either. This contradicts the extant literature around the importance of belonging to employee engagement and thus performance. The three constructs; working long hours, personal problems and lack of challenges could either mean they do not experience these or if they do they do not inhibit performance.

In conclusion, poor leadership seems to be by far the most important inhibitor of performance for ITO employees, followed by lack of job security, role clarity and access to resources. This study clearly shows that a sense of belonging (to either the client or 
employing organisation) which is often viewed as important to employee engagement is not important in either inhibiting and driving performance of these outsourced employees.

\section{Summary of Research Questions 1 and 2}

Figure 1 below uses the force field analysis technique of Lewin (Lewin, 1951; Connelly, 2016) applied to these findings. The vertical axis shows the possible level of performance. The horizontal line represents the current level of employee performance that could be raised or lowered by changes in the driving and the inhibiting forces. Driving forces direct behaviour positively away from equilibrium, known as the status quo, whereas restraining forces, direct behaviour towards reducing performance. The relative strength of each construct is represented by the length of the arrow. For example, disrespect from management is the biggest inhibitor of performance, whilst passion is the biggest driver of performance. Lewin argued that the way to ensure improvement is to reduce restraining forces rather than to add more driving forces (Pater, 2011). The diagram should be of interest to managers of ITO employees as it gives guidance on which factors to use to leverage increased performance. 
Figure 1: Force Field Analysis: Drivers and Inhibitors of Performance

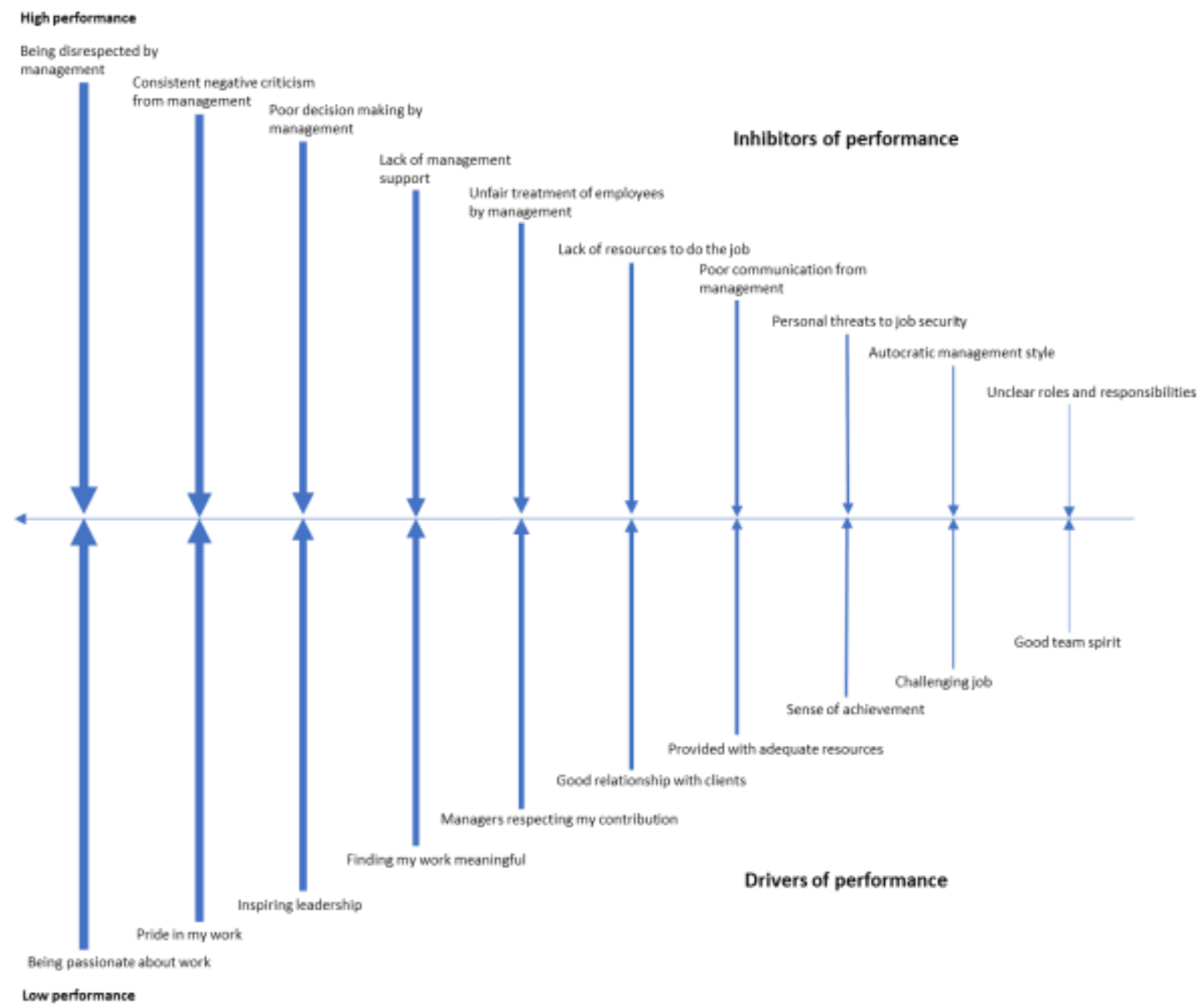

4.3 Research Question 3 - Do the perceptions of factors that influence ITO employees' performance differ between: ITO client managers, ITO service provider managers, highly and poorly performing ITO employees?

ITO client managers versus ITO service provider managers

The researchers assumed that the ITO client managers and the ITO service provider managers may view the importance of the 31 drivers and the 37 inhibiters differently. The t-tests on each of the constructs indicated that only in the case of participative decision making ( $p=0.032$ with ITO client managers seeing it as more important than the ITO 
managers) was there a significant difference of opinion between the two types of managers over the 68 variables. Hence from this point on the data for the two managers' groups are grouped together into one single sample named 'Managers' and were treated as a homogeneous sample. This is a significant finding in light of the notion that organisations should aim to satisfy or exceed the expectations of its stakeholders (Garvare and Johansson, 2010). In the case of ITO the two key stakeholder manager groups are congruent with the perceptions of performance drivers and inhibitors of ITO employees.

The t-tests with an alpha of 0.05 were then conducted between pairings of the three remaining stakeholder groups; managers, good performers and poor performers on each of the 68 variables. The table below shows the numbers of variables where there were significant differences between the groups.

Table 6: Number of Significant Differences Between Managers and Employees

\begin{tabular}{|l|c|c|l|l|}
\hline & $\begin{array}{l}\text { Total number of } \\
\text { variables }\end{array}$ & $\begin{array}{l}\text { Good v/s poor } \\
\text { performers }\end{array}$ & $\begin{array}{l}\text { Managers v/s poor } \\
\text { performers }\end{array}$ & $\begin{array}{l}\text { Managers v/s } \\
\text { good performers }\end{array}$ \\
\hline $\begin{array}{l}\text { Drivers of } \\
\text { Performance }\end{array}$ & 31 & 4 & 4 & 5 \\
\hline $\begin{array}{l}\text { Inhibitors of } \\
\text { Performance }\end{array}$ & 37 & 9 & 15 & 5 \\
\hline
\end{tabular}

It seems that there is a great deal of consensus over the importance of the drivers of performance but a lack of consensus over the inhibitors.

Drivers of performance

Table 7 below shows the five most highly ranked drivers of performance of ITO employees as viewed by the three stakeholder groups. 
Table 7: Top Five Drivers of Performance Across Three Groups

\begin{tabular}{|l|c|l|l|l|l|}
\hline \multicolumn{2}{|l|}{ Good Performers } & \multicolumn{2}{l|}{ Poor Performers } & \multicolumn{2}{l|}{$\begin{array}{l}\text { Managers (ITO client and ITO } \\
\text { managers) }\end{array}$} \\
\hline $\mathbf{N = 2 7}$ & Mean & N=28 & Mean & N=61 & Mean \\
\hline $\begin{array}{l}\text { Being passionate } \\
\text { about my work }\end{array}$ & 4.81 & $\begin{array}{l}\text { Being passionate } \\
\text { about my work }\end{array}$ & 4.61 & Inspiring leadership & 4.43 \\
\hline Pride in my own work & 4.78 & $\begin{array}{l}\text { Finding my work } \\
\text { meaningful }\end{array}$ & 4.43 & $\begin{array}{l}\text { Being provided with adequate } \\
\text { resources to do my job }\end{array}$ & 4.26 \\
\hline $\begin{array}{l}\text { Finding my work } \\
\text { meaningful }\end{array}$ & 4.56 & Pride in my own work & 4.32 & Managers respect my contribution & 4.26 \\
\hline Sense of achievement & 4.52 & $\begin{array}{l}\text { Flexible time and place } \\
\text { of work }\end{array}$ & 4.25 & Financial recognition & 4.21 \\
\hline $\begin{array}{l}\text { Understanding } \\
\text { manager }\end{array}$ & 4.48 & Trustworthy team & 4.11 & $\begin{array}{l}\text { My job enables me to achieve my } \\
\text { personal goals }\end{array}$ & 4.18 \\
\hline
\end{tabular}

An examination of the table above and a detailed analysis of the significant differences in the t-tests between the three groups, reveal a contradiction to the comments below the previous table on consensus about performance drivers. Although there are relatively few differences - these differences are critically important. The table shows that the managers assume that employees are driven extrinsically by the managers being inspiring and respectful of the employees' contribution, as well as the factors of pay (which in turn leads to the attainment of personal goals) and being provided with adequate resources. In contrast, both groups of employees state that they are driven intrinsically by passion, pride and finding the work meaningful.

When comparing the results of the t-tests between the managers and the good performers of what drives employee performance, there are five (out of a possible 31) significant differences, and every one of them are in the top five items as ranked by the good performers. In every case the good performers rated the four intrinsic factors of passion, pride, meaning from work, sense of achievement and then having an understanding manager, significantly higher than the managers did, while the managers top five factors are all extrinsic to the employee. Of the 4 significant differences of drivers of performance between managers and poor performers, two are in the most highly ranked items for each group i.e. all 4 fall in the top 5 listings. Poor performers saying their 
passion and having meaningful work were most important whist managers saying inspiring managers and resources are the most important. When looking at the 4 significant differences between the good and poor performers, 3 of them were amongst the good performers' top 5 - the good performers rated pride in one's work, sense of achievement and reporting to an understanding manager significantly higher than did the poor performers. The large mismatch between the managers and the employees in their understanding of the drivers of performance has important ramifications for the managers' ability to enable optimal performance from their staff. This gulf of misunderstanding aligns with the findings of Louw et al. (2012).

The managers' perception represents a transactional view of employees, who are seen to require resources and pay, as well as the managers to offer inspiration to them, in order to be motivated (Attridge, 2009; Bhanu, 2011). The data shows the employees are far more driven by deep seated intrinsic motivators that transcend situational factors. Maslow would call them higher order self-actualising motivators (Sadri and Bowen, 2011). While these factors can only be derived internally, managers can nurture them. Working with these deeper needs would require managers to use an individualised coaching style to connect with what truly matters for these knowledge workers (Ladegard and Gjerde, 2014). When these employees experience a sense of purpose, pride and achievement, they will be dedicated to their wok (Schaufeli, Bakker and Salanova, 2006) increasing the probability for innovative work (Gallup, 2013) and competitive advantage (Peteraf and Barney, 2003; Scrima, Lucrezia, Parry and Falgares, 2014). The data offers an opportunity for the managers to adjust the way they interact with both their high and poor performing employees.

Inhibitors of Performance

Table 8 below displays the top five inhibitors of performance as reported by the three stakeholder groups. 
Table 8: Top Five Inhibitors of Performance Across Three Groups

\begin{tabular}{|c|c|c|c|c|c|}
\hline \multicolumn{2}{|l|}{ Good Performers } & \multicolumn{2}{|l|}{ Poor Performers } & \multicolumn{2}{|c|}{$\begin{array}{l}\text { Managers (ITO client and ITO } \\
\text { managers) }\end{array}$} \\
\hline $\mathrm{N}=27$ & Mean & $\mathrm{N}=28$ & Mean & $\mathrm{N}=61$ & Mean \\
\hline $\begin{array}{l}\text { Being disrespected by } \\
\text { management }\end{array}$ & 4.33 & $\begin{array}{l}\text { Unfair treatment of } \\
\text { employees by } \\
\text { management }\end{array}$ & 3.96 & $\begin{array}{l}\text { Being disrespected by } \\
\text { management }\end{array}$ & 4.20 \\
\hline \begin{tabular}{|l|} 
Poor decision making by \\
managers
\end{tabular} & 4.30 & $\begin{array}{l}\text { Personal threats to job } \\
\text { security }\end{array}$ & 3.96 & $\begin{array}{l}\text { Lack of knowledge and skills } \\
\text { needed to do my work }\end{array}$ & 4.18 \\
\hline $\begin{array}{l}\text { Consistent negative } \\
\text { criticism from } \\
\text { management }\end{array}$ & 4.22 & $\begin{array}{l}\text { Lack of appropriate } \\
\text { resources to do the job }\end{array}$ & 3.89 & $\begin{array}{l}\text { Poor decision making by } \\
\text { managers }\end{array}$ & 4.16 \\
\hline \begin{tabular}{|l} 
Leadership \\
indecisiveness
\end{tabular} & 4.19 & $\begin{array}{l}\text { Poor working } \\
\text { conditions }\end{array}$ & 3.89 & Lack of management support & 4.15 \\
\hline Bureaucracy & 4.19 & $\begin{array}{l}\text { Poor communication } \\
\text { from management }\end{array}$ & 3.86 & $\begin{array}{l}\text { Consistent negative criticism } \\
\text { from management }\end{array}$ & 4.10 \\
\hline
\end{tabular}

In this case, there is a great deal of alignment between the thinking of the good performers and that of the managers with both groups acknowledging that employees are very negatively affected by poor management practices and suggests that managers need to adopt a particular way of interacting with their best performing staff. Starratt and Grandy (2010) and Kernan et al.(2011) found that abusive leadership causes feelings of hopelessness, humiliation and anxiousness at a personal level and result in employee turnover and a destructive organisational culture. These findings relate to the need for authentic ethical leadership (Avolio and Gardner, 2005) where leaders instil trust in their followers.

Only 1 of the 5 (out of a possible 37) significant differences between managers and good performers fell in the top five of either group, that is the high importance given by the managers to lack of knowledge and skills to do one's work, showing that the managers do not view the employees as being fully competent - a view not shared by the high performing employees. 
The table shows clearly that the poor performers' view of what inhibits their performance differs from that of the other two stakeholder groups. Between the good and poor performers there were 9 significant differences, 4 of these were in the good performers' top 5 - showing how poor management practices inhibits good performers far more so than poor performers. The lack of any overlap between the top 5 ranked items between the good and poor performers and between the managers and poor performers as well as the 15 (out of a possible 37) significant differences of opinions between poor performers and managers, shows the wide gulf in understanding about what inhibits performance. The managers hold themselves responsible for inhibiting performance and their 3 highest ranked inhibitors were significantly different to the opinions of the poor performers. The themes underpinning their top 5 inhibitors are around an external locus of control and a "victim mentality" (Amabile et al.,1994). They are concerned with unfairness, threats around job security, lack of resources, poor working conditions and poor communication from one's manager, these are all related to extrinsic drivers of motivation and Maslow's lowest order needs for security.

\section{Conclusion to research question 3}

These findings demonstrate significant differences between the three stakeholder groups which have important ramifications for the way in which managers optimise the performance of their ITO staff. Mayfield and Mayfield (2011) established that there are differences between poor and good performers, and that managers need to understand these differences so that they may manage these groups differently. The findings are of interest in showing an alignment between the ideas of managers and good performers with regard to inhibitors but not with the drivers whereas the attributions of the poor performers are aligned with the good performers around the drivers but are very different to the two other stakeholder groups with regard to the inhibitors. This builds on the findings of Ferguson et al. (2010). The very significant differences between the managers and the two employee groups around the most important drivers of performance build on the findings on Louw et al. (2012). It is beyond the scope of this study to comment whether the different views between the two types of employees are inherent or arise from the 
way they are currently being managed. These findings are new additions to the literature on ITO.

\section{Conclusion and Contribution of the Study}

The aim of this study was to determine empirically, the factors that drive and inhibit performance of ITO employees and compare the results between the ITO stakeholders. The force field analysis in Figure 1 clearly shows that intrinsic factors are the key drivers of performance, whilst poor leadership is the main inhibitor of performance, which is the most important factor to address.

In order to summarise the findings, Table 9 and Figure 2 below depict the important differences in the perceptions of the motivation of ITO employees by the three stakeholder groups, as shown in the tables above, mapped onto some of theory. It shows that the top performers tend to have higher order and intrinsic motivators, compared to poor performers, who have a mixture of extrinsic and intrinsic needs. The critical finding of the managers' misaligned expectation that employees are focussed on extrinsic motivators, is also demonstrated.

Table 9 Motivation of ITO Employees as Perceived by the Three Stakeholder Groups

\begin{tabular}{|l|c|c|c|c|}
\hline \multirow{2}{*}{ Groups } & \multicolumn{2}{|c|}{ Extrinsic Motivation } & \multicolumn{2}{c|}{ Intrinsic Motivation } \\
\cline { 2 - 5 } & $\begin{array}{l}\text { Level 4 } \\
\text { Safety Needs }\end{array}$ & $\begin{array}{l}\text { Level 3 } \\
\text { Relationship with } \\
\text { Manager }\end{array}$ & $\begin{array}{l}\text { Level 2 } \\
\text { Esteem } \\
\text { Needs }\end{array}$ & $\begin{array}{l}\text { Level 1 } \\
\text { Self- } \\
\text { Actualization } \\
\text { Needs }\end{array}$ \\
\hline $\begin{array}{l}\text { Poor } \\
\text { performers }\end{array}$ & $\mathrm{X}$ & $\mathrm{X}$ & $\mathrm{X}$ & \\
\hline $\begin{array}{l}\text { Top } \\
\text { performers }\end{array}$ & & $\mathrm{X}$ & $\mathrm{X}$ & $\mathrm{X}$ \\
\hline $\begin{array}{l}\text { Managers' } \\
\text { expectations }\end{array}$ & $\mathrm{X}$ & $\mathrm{X}$ & & \\
\hline
\end{tabular}




\section{Figure 2: Findings mapped onto on intrinsic and extrinsic motivation and on Maslow's hierarchy of needs}

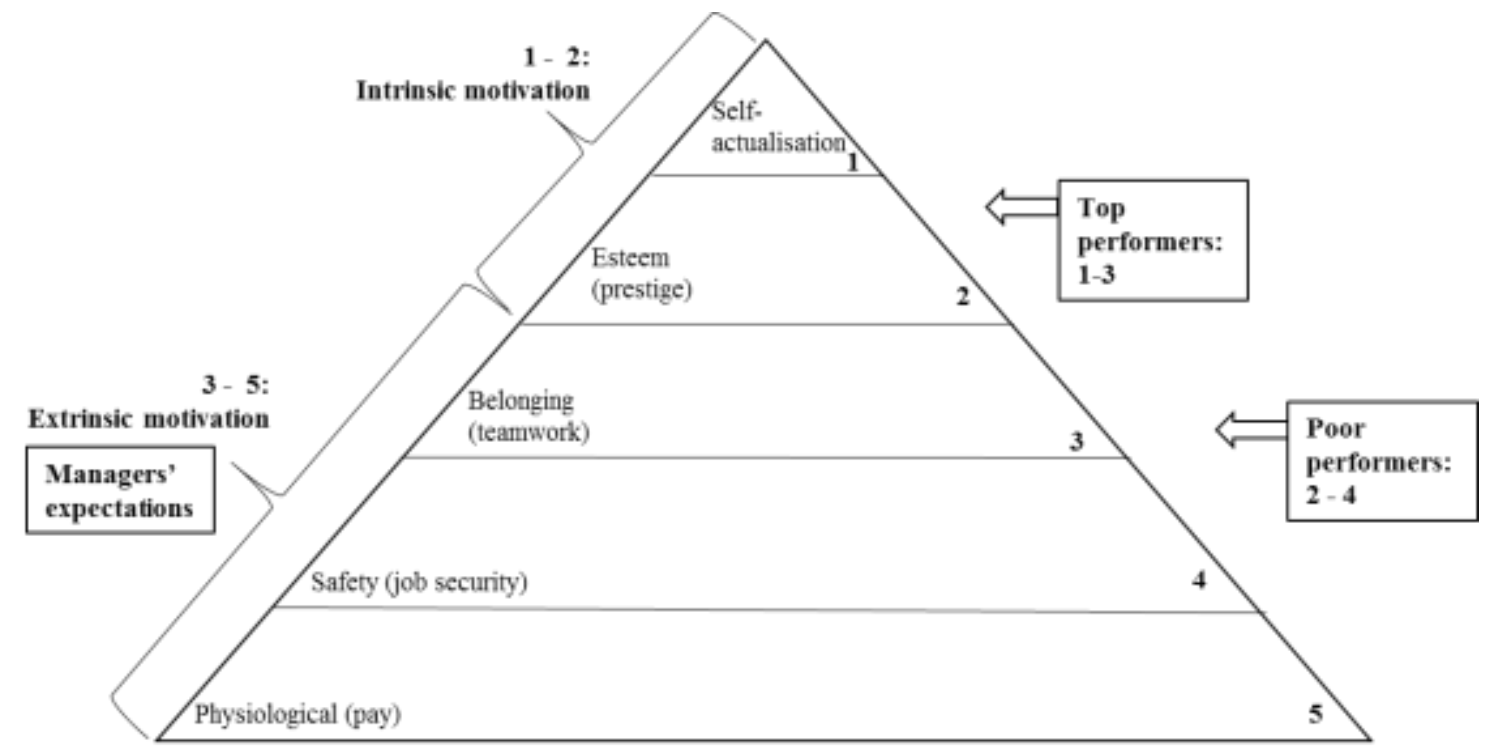

Source: Authors' own

These findings, demonstrating the large gap in perceptions about the key drivers and inhibiters of performance, present opportunities to unlock overall organisational performance particularly as poor performers can adversely affect good performers' motivation and effectiveness (Ferguson et al., 2010). Interestingly, 'Being Passionate about my work' is the only variable that the poor performers rated higher that the managers. Managers need to pay attention to this important construct as studies have found that passion is aligned with self-defining activities that employees value (Vallerand, Paquet, Philippe and Charest, 2010). The findings show that good performers are highly engaged and that they value activities that are aligned to their internal identity and values, with sense of meaning and achievement, pride and passion in their work being the main drivers of performance (Vallerand et al., 2010; Mirvis, 2012). It would seem that good performers have a high internal locus of control and a low external attribution when it comes to performance (Lepine and Van Dyne, 2001). This finding is in alignment with the theory of achievement which suggests that "achievement-oriented behaviour differs 
across individuals and is a critical factor that motivates individuals to succeed" (Hsu et al., 2010, p. 1594).

To get the most out of ITO employees, managers need to recognise that what they perceive to be the drivers of performers, differ from those of the employees. The managers therefore need to communicate regularly with the ITO employees to exchange expectations. Employee performance is largely intrinsically driven and it has implications for both selection as well as designing work and feedback systems to enable a feeling of pride, fulfilment and meaning. Managers need to realise that their poor management has an inhibiting effect on the good performers and thus need to adapt their management style to the level of performance of employees. They need to support, but not micromanage the good performers, whilst holding poor performers accountable and thus developing an internal locus of control within them. On the other hand, extrinsic factors are mostly under the control or influence of managers post recruitment and selection processes. 'Lack of Support' and 'Unfair treatment of employees' have also been highlighted as key inhibitors. This sends a clear message to managers to develop objective and transparent human resource processes that will attempt to address these issues.

One of the key findings of this study is that ITO client managers and ITO managers share the same perception with regard to factors that influence performance of ITO employees. This finding makes it easier for both parties to collaborate in managing outsourced employees and to capitalize on this alignment to enhance the partnership. However, they need to realise that although they agree with each other - they see things very differently to the employees. The big discrepancies in the perceptions of poor performers and management particularly where inhibitors are concerned need to be responded to by the managers to unlock the poor performers' potential. The results show clearly that poor leadership practices have a huge impact on the employees and thus the success of outsourcing partnerships. Organisations need to ensure there is regular feedback to managers on their performance and subsequent leadership development to avoid the long term negative impact on employees. 
For outsourced employees to perform optimally, some key intrinsic factors must be fulfilled. Passion and pride, aligned to a meaningful job role will unleash outstanding performance. Managers must ensure that the structure of the work and the ongoing feedback to the employees enable these intrinsic motivators to be experienced. Employees must be mindful of these needs when choosing a new position or even a new assignment at work. Poorly performing employees should revaluate whether their purpose is aligned to their current job and consider changing roles to ensure good job fit and ultimately improve performance. Furthermore, employees must "identify people who will help them to feel inspired and spend more time with them, [and] also find out how others are inspired and try their methods" (Westwood, 2008, p. 64). Individualised attention in the form of one-on-one coaching of poorly performing employees to ascertain their personal purpose and to align these to their organisation's needs will enhance the performance of the employee (Ladegard and Gjerde, 2014; Scheepers, 2012). Organisations could benefit from investing in customised leadership development of managers in these contexts.

\subsection{Recommendations for Future Research}

Seeing that leadership has emerged as a very important driver and inhibitor of performance, the different power bases of the two types of managers and the psychological contracts between them and the outsourced employees, could be a fruitful area of investigation. The differences in perceptions between good and poor performers should be explored in other industries. A study to understand what drives innovation within the ITO industry will unlock value to the stakeholders.

ITO employees are vital to the future of the modern firm; therefore, understanding what drives and inhibits their performance will become increasingly important. This study has identified the key drivers and inhibitors of performance and highlighted key areas of misunderstanding between managers and good and poor performers. It is hoped that these findings will enable managers to become more effective in managing the range of performers that report to them and in this way, increases the satisfaction of all stakeholders in the tripartite relationship in information technology outsourcing. 


\section{References}

Abboubi, M.E. and Cornet, A. (2012), "Towards a dynamic stakeholder management framework for CSR certifications", International Journal of Business and Social Science, Vol. 3 No. 4, pp.1-12.

Abu-Musa, A.A. (2011), "Exploring information systems/technology outsourcing in Saudi organizations: An empirical study", Journal of Accounting, Business \& Management, Vol. 18 No. 2, pp. 17-73.

Al-Gharbi, K., Al-Kindi, A. and Al-Salti, Z. (2009), "IT /IS outsourcing from Omani organizations' perspective: Motivations and reservations", International Journal of Management Innovation Systems, Vol. 1 No. 1, pp. 1-10.

Amabile, T.M., Hill, K.G., Hennessey, B.A. and Tiche, E.M. (1994), "The work preference inventory: assessing intrinsic and extrinsic motivation orientations", Journal of Personality and Social Psychology, Vol. 34 No. 5, pp. 950-967.

Assudani, R. and Kloppenborg, T. J. (2010), "Managing stakeholders for project management success: an emergent model of stakeholders", Journal of general management, Vol. 35 No. 3, pp. 67-80.

Attridge, M. (2009), "Measuring and managing employee work engagement: a review of the research and business literature", Journal of Workplace Behavioural Health, Vol. 24, pp. 383-398.

Avolio, B. and Gardner, W.L. (2005), "Authentic leadership development: Getting to the root of positive forms of leadership", Leadership Quarterly, Vol. 16, pp. 315-338.

Baldonado, A.M. and Spangenburg, J. (2009), "Leadership and the future: Gen Y workers and two-factor theory", The Journal of American Academy of Business, Vol. 15 No. 1, pp. 99-103.

Bhagat, P., Byramjee, F. and Taiani, V. (2010), "A framework of total value orientation for strategic outsourcing decisions", Competitiveness Review, Vol. 20 No. 4, pp. 305321.

Bhanu, S. (2011), "Effect of pay satisfaction in information technology enabled sector in India", Journal of Management Research, Vol. 11 No. 2, pp. 112-128.

Blair, M.M., O'Connor, E.O. and Kirchhoefer, G. (2011), "Outsourcing, modularity, and the theory of the firm. Brigham Young University Law Review", Vol. 2 No. 1, pp. 263314.

Bristow, D., Amyx, D., Castleberr, S.B. and Cochran, J.J. (2011), "A cross-generational comparison of motivational factors in a sales career among Gen- $X$ and Gen- $Y$ college students", Journal of Personal Selling \& Sales Management, Vol. 31 No. 1, pp. 77-85. Brooks, N.G., Miller, R.E. and Korzaan, M.L. (2009), "IT workers on outsourcing: What about me? What about the profession?", Academy of Information and Management Sciences Journal, Vol. 12 No. 1, pp. 1-12.

Carleton, K. and Canada, E. (2011), "How to motivate and retain knowledge workers 
in organizations: A review of literature", International Journal of Management, Vol. 28 No. 2, pp. 459-467.

Choudhuri, B., Maguire, S. and Ojiako, U. (2009), "Revisiting learning outcomes from market led ICT outsourcing", Business Process Management Journal, Vol. 15 No. 4, pp. 569-587.

Clarke, R., Chandra, R. and Machado, M. (2016), "SMEs and social capital: exploring the Brazilian context", European Business Review, Vol. 28 No. 1, pp. 2-20.

Connelly, M. (2016), "Force field analysis Kurt Lewin", available at: http://www.changemanagement-coach.com/force-field-analysis.html (accessed 10 December 2016).

Danish, R.Q. and Usman, A. (2010), "Impact of reward and recognition on job satisfaction and motivation: An empirical study from Pakistan", International Journal of Business and Management, Vol. 5 No. 2, pp. 159-167.

Davis-Blake, A. and Broschak, J.P. (2009), "Outsourcing and the changing nature of work", Annual Review of Sociology, Vol. 35, pp. 321-340.

De Carvalho, V.D.H., Poleto, T. and Seixas, A.P.C. (2017), "Information technology outsourcing relationship integration: a critical success factors study based on ranking problems (P.y) and correlation analysis", Expert Systems, e12198, pp. 1-12.

Deci, E.L. and Ryan, R.M. (2000), "The 'what' and 'why' of goal pursuits: human needs and the self-determination of behaviour", Psychological Inquiry, Vol. 11 No. 4, pp. 227268.

Denton, K.D. (2010), "Creating a self-confident workforce", Journal for Quality \& Participation, Vol. 33 No. 3, pp. 9-38.

Drummond, J. (2010), "The company-client relationship and the retention of staff in the IT consulting industry: A psychological contract perspective", MBA Dissertation, University of Pretoria. Republic of South Africa.

Elmuti, D., Grunewald, J. and Abebe, D. (2010), "Consequences of outsourcing strategies on employee quality of work life, attitudes, and performance", Journal of Business Strategies, Vol. 27 No. 2, pp. 178-203.

Farndale, E., Hope-Hailey, V. and Kelliher, C. (2011), "High commitment performance management: the roles of justice and trust", Personnel Review, Vol. 40 No. 1, pp. 5-23. Ferguson, A.J., Ormiston, M.E. and Moon, H. (2010), "From approach to inhibition: The influence of power on responses to poor performers", Journal of Applied Psychology, Vol. 95 No. 2, pp. 305-320.

Fu, J.-R. (2010), "Is information technology career unique? Exploring differences in career commitment and its determinates among IT and Non-IT employees", International Journal of Electronic Business Management, Vol. 8 No. 4, pp. 272-281. Gallup, INC. (2013), State of the American Workplace: Employee engagement insights for US business Leaders., Gallup, INC, Washington.

Garvare, R. and Johansson, P. (2010), "Management for sustainability - A stakeholder theory", Total Quality Management, Vol. 21 No. 7, pp. 737-744. 
Goo, J., Kishore, R., Rao, H.R. and Nam, K. (2009), "The role of service level agreements in relational management of information technology outsourcing: and empirical study", MIS Quarterly, Vol. 33 No. 1, pp. 119-145.

Gorla, N. and Lau, M. (2010), "Will negative experiences impact future outsourcing?", Journal of Computer Information Systems, Vol. 50 No. 3, pp. 91-101.

Guha, A.B. (2010), "Motivators and hygiene factors of generation X and generation YThe test of two-factor theory", Journal of Management, Vol. 7 No. 2, pp. 121-132.

Hameed, A. and Waheed, A. (2011), "Employee development and its effect on employee performance: A conceptual framework", International Journal of Business and Social Science, Vol. 2 No. 13, pp. 224-229.

Harell, G. and Daim, T.U. (2010), "HDM modelling as a tool to assist management with employee motivation: The case of silicon forest", Engineering Management Journal, Vol. 22 No. 1, pp. 23-33.

Higgs, M. (2009), "The good, the bad and the ugly: Leadership and narcissism", Journal of Change Management, Vol. 9 No. 2, pp. 165-178.

Hirschi, A. (2011), "Effects of orientations to happiness on vocational identity achievement", The Career Development Quarterly, Vol. 59 No. 4, pp. 367-378.

Hsu, H.-Y., Chen, S.-H., Yu, H.-Y. and Lou, J.-H. (2010), "Job stress, achievement motivation and occupational burnout among male nurses", Journal of Advanced Nursing, Vol. 66 No. 7, pp. 1592-1601.

lqbal, Z. and Munir Dad, A. (2013), "Outsourcing: A review of trends, winners \& losers and future trends", International Journal of Business and Social Science, Vol. 4, No. 8, pp. 91-107.

Jayasingam, S., Govindasamy, M. and Garib Singh, S.K. (2010), "Instilling affective commitment: insights on what makes knowledge workers want to stay", Management Research Review, Vol. 39 Vol. 3, pp. 266-288.

Johnson, R.B. and Onwuegbuzie, A.J. (2004), "Mixed methods research: a research paradigm whose time has come", Educational Researcher, Vol. 33 No. 7, pp. 14-26.

Kaufman, J. (2009), "Rewards that encourage engagement", Occupational Health and Safety, Vol. 43 No. 10, pp. 54-56.

Kernan, M.C., Watson, S., Chen, F.F. and Kim, T.G. (2011), "How cultural values affect the impact of abusive supervision on worker attitudes", Cross Cultural Management, Vol. 18 No. 4, pp. 464-484.

Lacity, M.C., Khan, S., Yan, A. and Willcocks, L.P. (2010), "A review of the IT outsourcing empirical literature and future research directions", Journal of Information Technology, Vol. 25 No. 1, pp. 395-433.

Ladegard, G. and Gjerde, S. (2014), "Leadership coaching, leader role-efficacy, and trust in subordinates. A mixed methods study assessing leadership coaching as a leadership development tool", Leadership Quarterly, Vol. 25 No. 4, pp. 631-646.

Lamm, E. and Meeks, M.D. (2009), "Workplace fun: the moderating effects of 
generational differences", Employee Relations, Vol. 31 No. 6, pp. 613-631.

Lee, H. and Dalal, R.S. (2011), "The effects of performance extremities on ratings of dynamic performance", Human Performance, Vol. 24 No. 2, pp. 99-118.

Leon, R.-D. (2011), "Creating the future knowledge worker", Management \& Marketing, Vol. 6 No. 2, pp. 205-222.

Lepine, J.A. and Van Dyne, L. (2001), "Peer responses to low performers: an attributional model of helping in the context of groups", Academy of Management Review, Vol. 26 No. 1, pp. 67-84.

Lewin, K. (1951), Field Theory in Social Science, Harper \& Row, New York, NY.

Littau, P., Jujagiri, N.J. and Adlbrecht, G. (2010), "25 years of stakeholders' theory in project management literature (1984 -2009)", Project Management Journal, Vol. 41 No. 4, pp. 17-29.

Louw, K., Sutherland, M. and Hofmeyr, K. (2012), "Enabling factors of productive organisational energy", South African Journal of Labour Relations, Vol. 36 No. 2, pp. 929.

Mandrinos, S. and Mahdi, N.M.N. (2016), "Examining knowledge gap and Psychic Distance Paradox interdependence: An exploratory inquiry", European Business Review, Vol. 28 No. 1, pp. 96-114

Maslow, A.H. (1943), "A theory on human motivation", Psychological Review, Vol. 50, pp. 370-396.

Mayfield, M. and Mayfield, J. (2011), "Effective performance feedback for learning in organizations and organizational learning", Development and Learning in Organizations, Vol. 26 No. 1, pp. 15-18.

Mcivor, R. (2011), "Outsourcing done right", Industrial Engineer: IE, Vol. 43 No.1, pp. 3035.

Mehta, N. and Mehta, A. (2010), "It takes two to tango: How relational investments improve IT outsourcing partnerships", Communications of the ACM, Vol. 53 No. 2, 160164.

Mirvis, P. (2012), "Employee engagement and CSR: Transactional, relational, and developmental approaches", California Management Review, Vol. 54 No. 4, pp. 93-117. NASSCOM (2015), "Global sourcing: continuous to outgrow IT-BPM spend", available at: http://www.nasscom.in/global-sourcing (accessed 28 May 2017).

Oshri, I., Kotlarsky, J. and Willcocks, L.P. (2015), Handbook of Global Outsourcing and Offshoring, Second edition, Palgrave Macmillan, London.

Paarlberg, L.E. and Lavigna, B. (2010), "Transformational leadership and public service motivation: Driving individual and organizational performance", Public Administration Review, Vol. 70 Vol. 5, pp. 710-718.

Padin, C., Svensson, G. and Wood, G. (2016), "A model of pilgrimage tourism: process, interface, people and sequence", European Business Review, Vol. 28 No. 1, pp. 77-95. 
Pater, R. (2011), "Six safety leadership strategies", Professional Safety, Vol. 56 No. 10, pp. 16-18.

Perry, S.J., Hunter, E.M. and Currall, S.C. (2016), "Managing the innovators: Organizational and professional commitment among scientists and engineers", Research Policy, Vol. 45 No. 6, pp. 1247-1262.

Peteraf, M.A. and Barney, J.B. (2003), "Unravelling the resource-based tangle", Managerial and Decision Economics, Vol. 24 No. 4, pp. 309-323.

Pratt, M. (2009), "For the lack of a boilerplate: Tips on writing up (and reviewing) qualitative research", Academy of Management Journal, Vol. 52 No. 5, pp. 856-862. Pryor, M.G., Singleton, L.P., Taneja, S. and Humphreys, J.H. (2010), "Workplace fun and its correlates: A conceptual inquiry", International Journal of Management, Vol. 27 No. 2, pp. 294-302.

Sadri, G. and Bowen, C.R. (2011), "Meeting employee requirements", Industrial Engineer, Vol. 43 No. 10, pp. 44-48.

Saklani, D.R. (2010), "Non-managerial perspective of quality of work Life", Journal of Management Research, Vol. 10 No. 2, pp. 87-102.

Schaufeli, W., Bakker, A. and Salanova, M. (2006), "The measurement of work engagement with a short questionnaire", Education and Psychological Measurement, Vol. 66 No. 4, pp. 701-716.

Scheepers, C.B. (2012). Coaching Leaders: The 7 ' $P$ ' Tools to Propel Change, Knowres, Randburg.

Schraeder, M. and Jordan, M. (2011), "Managing performance: A practical perspective on managing employee performance", The Journal for Quality and Participation, Vol. 34 No. 2, pp. 4-10.

Scrima, F., Lucrezia, L., Parry, E. and Falgares, G. (2014), "The mediating role of work engagement on the relationship between job involvement and affective commitment", The International Journal of Human Resources Management, Vol. 25 No. 15, pp. 21592173.

Sharabi, M. and Harpaz, I. (2010), 'Improving employees' work centrality improves organizational performance: work events and work centrality relationships", Human Resource Development International, Vol. 13 No. 4, pp. 379-392.

Sharkie, R. (2009), "Trust in leadership is vital for employee performance", Management Research News”, Vol. 32 No. 5, pp. 491-498.

Solli-Sæther, H. (2011), "Transplants' role stress and work outcome in IT outsourcing relationships. Industrial Management and Data Systems", Vol. 111 No. 2, pp. 227-245. Staren, E.D. (2009), "Optimizing staff motivation”, Physician Executive, Vol. 35 No. 4, pp. 74-77.

Starratt, A. and Grandy, G. (2010), "Young workers' experiences of abusive leadership", Leadership \& Organization Development Journal, Vol. 31 No. 2, pp. 136-158. 
Stringer, C., Didham, J. and Theivananthampillai, P. (2011), "Motivation, pay satisfaction, and job satisfaction of front-line employees", Qualitative Research in Accounting and Management, Vol. 8 No. 2, pp. 161-179.

The Statistics Portal (2016). Global market size of outsourcing market size from 2000 to 2015 (in billion US dollars), available at: https://www.statista.com/statistics/189788/global-outsourcing-market-size/ (accessed 30 October 2016).

The Statistics Portal (2016). Total contract value of the information technology outsourcing (ITO) market worldwide from 2000 to 2015 (in billion US dollars), available at: https://www.statista.com/statistics/190122/total-gloabl-contract-value-informationtechnology-outsourcing/ (accessed 19 June 2017).

Thomas, J.P., Whitman, D.S. and Viswesvaran, C. (2010), "Employee proactivity in organizations: A comparative meta-analysis of emergent proactive constructs", Journal of Occupational and Organizational Psychology, Vol. 83 No. 1, pp. 275-300.

Vallerand, R.J., Paquet, Y., Philippe, F.L. and Charest, J. (2010), "On the role of passion for work in burnout: A process model", Journal of Personality, Vol. 78 No. 1, pp. 289-312. Van Quaquebeke, N., Zenker, S. and Eckloff, T. (2008), "Find out how much it means to Me! The Importance of interpersonal respect in work values compared to perceived organizational practices", Journal of Business Ethics, Vol. 89 No. 3, pp. 423-431.

Wagner, D. (2006), "Success factors in outsourcing service jobs", MIT Sloan Management Review, Vol. 48 No. 1, pp. 6-7.

Walsh, J. and Deery, S. (2006), "Refashioning organizational boundaries: Outsourcing customer service work", Journal of Management Studies, Vol. 43 No. 3, pp. 0022-2380. Westwood, C. (2008), "Become an inspirational leader", Nursing Standard, Vol. 23 No. 11, pp. 64- 64.

Windrum, P., Reinstaller, A. and Bull, C. (2009), "The outsourcing productivity paradoxical outsourcing, organisational innovation, and long run productivity growth", Journal of Evolutionary Economics, Vol. 19 No. 2, pp. 197-229.

Yin, R.K. (2011), Qualitative Research from Start to Finish. Guilford Press, Guilford Publications, Inc, New York, NY.

Yousaf. A., Yang, H. and Sanders, K. (2015), "Effects of intrinsic and extrinsic motivation on task and contextual performance of Pakistani professionals: The mediating role of commitment foci", Journal of Managerial Psychology, Vol. 30 No. 2, pp. 133-150.

Zikmund, W.G., Babin, B.J., Carr, J.C. and Griffin, M. (2010), Business Research Methods (8th ed.). South-Western Cengage learning, Canada. 